\title{
The Connotations of Language Teacher Autonomy
}

\author{
Ligang $\operatorname{Han}^{1}$ \\ ${ }^{1}$ English Department, North China Electric Power University, Baoding, Hebei, China \\ Correspondence: Ligang Han, English Department, North China Electric Power University, Baoding, Hebei, \\ China. E-mail: liganghan@163.com
}

Received: August 28, 2017 Accepted: September 12, 2017 Online Published: September 14, 2017

doi: 10.5539/elt.v10n10p134 URL: http://doi.org/10.5539/elt.v10n10p134

\begin{abstract}
With the research on the development of learner autonomy in foreign language education, teacher autonomy has become a hot topic in the research of foreign language teacher education. However, it is the most difficult question to define language teacher autonomy and any answer to it is likely to be subjective. On the basis of expounding upon the different definitions concerning the research on teacher autonomy in language teaching and learning, the focus of the present paper is to clarify the connotations of language teacher autonomy and a working definition is made.
\end{abstract}

Keywords: teacher autonomy, language teacher, teacher education

\section{Introduction}

Autonomy has become a hot topic in the research of foreign language education. The idea of autonomy in language learning originated in the late 1960s through the adult movement in Europe and North America, and for many years it continued to be associated with adult learners who had left formal education (Benson, 2004). Thus early work on autonomy was mainly concerned with learners who were learning on their own.

In 1981, Holec's book Autonomy and Foreign Language Learning was published, signifying the very beginning of research on autonomy. Since then, learner autonomy has gained momentum and become the focus of relevant research in the past three decades. Generally, autonomy can be interpreted as the capability/ability of taking charge of one's own study.

As more and more researchers do research on learner autonomy, they come to realize that language teachers play a very important role during the process of the development of learner autonomy. Language teachers need to adjust their roles to help language learners to develop their autonomy, the roles which are expected to be distinct from old ones carried out in the traditional teaching context.

With the research on the roles that language teachers play in promoting the development of learner autonomy, teacher autonomy has become a hot topic in the research of foreign language education and teacher education.

It is important to clarify what teacher autonomy connotates before a detailed elaboration on the promoting process. Therefore, in this paper, on the basis of expounding upon the different definitions concerning the research on teacher autonomy in language teaching and learning, the focus is upon a working definition for language teacher autonomy.

\section{Teacher Autonomy and Learner Autonomy}

Developing learner autonomy has gradually been regarded as the ideal objective of foreign language education (Little, 1991), and the major manifestation of effective teaching and learning. Thus, how to develop language learner autonomy has become a major concern for foreign language teachers and researchers. Many researchers (e.g. Aoki, 2000, 2002; Dickinson, 1992; Pang, 2003; Xu, 2007) acknowledge that foreign language teacher is an important factor that influences the development of learner autonomy. Foreign language teacher directly or indirectly influences the internal or external factors that affect the development of learner autonomy. In brief, foreign language teacher is a major factor that influences the development of learner autonomy. For foreign language teachers, it is not only their ethical responsibility to develop learners' foreign language communicative competence, but also more importantly, to help learners to develop their autonomy.

One criterion to evaluate the degree of teacher autonomy is embodied in foreign language teachers' endeavor and roles in developing learner autonomy. From early researches on learner autonomy, researchers have been 
exploring the roles that foreign language teachers play in promoting learner autonomy. Cotterall (1995) identifies two main categories of roles that foreign language teachers play: "authority" and "facilitator". Benson (2005, 2011) goes further and states that foreign language teachers are "facilitator", "helper", "coordinator", "counselor", "consultant", "advisor", "knower" and "resource" in the process of promoting learner autonomy.

Voller (1997) explicates the three kinds of roles that teachers play in developing learner autonomy. The first one is "facilitator". The ideal of the teacher as a facilitator of learning, or a helper to facilitate learning, is probably the most commonly used terms in the discussion of autonomous learning. Knowles (1975) was among the earliest theorists to use and define the term facilitator. Holec (1985, cited from Voller, 1997) characterizes the roles as the provision of psycho-social support and technical support. Similarly, Xu (2007) states that as a facilitator to promote learner autonomy, foreign language teacher should create a good learning environment, activate learners' initiative and motivation, raise their autonomous learning awareness, encourage learners actively construct their knowledge and develop language competence. In addition, according to the individual learner differences, language teacher should help learners set up learning objectives, select learning materials, organize language practices, so that learners can acquire the language knowledge and improve their language competence. Finally, language teacher also need to help learners to evaluate their learning.

The second role is "counselor" (Voller, 1997). In foreign language learning, learners' affect factors, such as emotion, mood, interest, motivation, attitude and anxiety will influence their learning behavior and outcome (Arnold, 2000). Therefore, as "counselor", language teachers should be aware of the negative affect factors that may hinder learning, and help learners to reduce and ease them.

The third role is "resource" (Voller, 1997). Language teachers are the resource of knowledge and skills for the students. In one sense, foreign language teachers need to have a good command of the knowledge of foreign language and theories of foreign language learning. Foreign language teachers are not only the source of information, but also are capable of developing learners' ability to use learning resources effectively and efficiently. Foreign language teachers should seek the balance between resource providers and guide (Breen \& Mann, 1997). However, most foreign language teachers do not simply play the role of "talking encyclopedia" in the process of developing learner autonomy $(\mathrm{Xu}, 2007)$. Therefore, it is far from enough to consider that foreign language teacher only as "resource".

Huang and Benson (2007) summarize the roles and functions that language teachers play in the development of learner autonomy. They include language teachers play the roles as "bridge", "facilitation", "scaffolding", "negotiation and dialogue", "mediation" and "critical stance towards teaching" (Huang \& Benson, 2007).

In brief, foreign language teachers need to be aware of their roles and function in the development of learner autonomy. In the first place, while setting up the curriculum objectives, language teachers should consider not only how to cultivate language learners' communicative competence according to individual differences, but also raise their awareness to help learners develop their learner autonomy in pedagogical practices. That is to help learners to learn how to learn (Holec, 1981).These two objectives are to be integrated and cannot be treated as the precondition of one for the other. In the second place, during the process of foreign language learning, the more teachers offer timely guide and scaffolding, the more language learners will consciously monitor and become responsible for their learning. In the third place, language learners need teachers to guide them in setting learning objective, selecting learning content and material, acquiring learning strategy and offering feedback for their learning outcome.

Some researchers (e.g. Aoki, 2002; Breen \& Mann, 1997; Little, 1995) assert that learner autonomy and teacher autonomy are interdependent. Just as Aoki (2002) explains that learner autonomy and teacher autonomy are like the two sides of a coin. Therefore, it is important to explore what teacher autonomy connotes and study the mechanism for the development of teacher autonomy based on the connection between learner autonomy and teacher autonomy.

\section{Connotations of Teacher Autonomy in Language Teaching and Learning}

Contrasted with the tremendous interest in the study of learner autonomy, the study of teacher autonomy has not gained momentum so far. For one thing, just like the difficulty in defining learner autonomy, there is no commonly accepted definition of teacher autonomy. For another, teacher autonomy is associated with many other aspects of teacher development, for example, teacher learning, teacher belief, and teacher reflection.

\subsection{Definitions of Teacher Autonomy}

Defining teacher autonomy has never been an easy task. This is probably the single most difficult question to answer about teacher autonomy in language teaching and learning, thus any answer to it is likely to be subjective. 
According to $\mathrm{Xu}$ (2007), the main reason for the difficulty in defining the concept of teacher autonomy lies in the multi-roles of language teacher. On one hand, language teacher is an instructor to the students. On the other hand, language teacher is a teacher researcher and a teacher learner as well.

In general teacher education, teacher autonomy like many educational variables, exists along a continuum. The increases in autonomy should mirror increases in "teacher status" in terms of teacher experience, expertise, and excellence (Anderson, 1987).

The following table is a brief summary of the definitions that researchers have been trying to define teacher autonomy (TA).

Table 1. Some definitions of teacher autonomy proposed by researchers

\begin{tabular}{ll}
\hline Reference & Definitions of TA \\
\hline Little (1995, p. 179) & $\begin{array}{l}\text { Capacity for autonomous } \\
\text { teaching }\end{array}$
\end{tabular}

Description
Genuinely successful teachers have always been autonomous in the sense of having a strong sense of personal responsibility for their teaching, exercising via continuous reflection and analysis the highest possible degree of affective and cognitive control of the teaching process, and exploiting the freedom that this confers.

$\begin{array}{ll}\text { McGrath (2000) } & \begin{array}{l}\text { Self-directed professional } \\ \text { development and Freedom } \\ \text { (from control by others) }\end{array}\end{array}$

Smith (2003, p. 4) professional action and professional development

Thavenius (1999, p. Teacher's ability and

160) willingness

160) willingness

Teacher has control over his/her own professional development. A number of strands come together: the teacher as researcher, action research, the concept of reflective practitioner and teacher development.

In relation to professional action, it includes the dimensions of "Self-directed professional action", "Capacity for self-directed professional action" and "Freedom from control over professional action". In relation to professional development, it includes the dimensions of "Self-directed professional development", "Capacity for self-directed professional development" and "Freedom from control over professional development".

Vieira (2008, p. 200) teacher-as-learner autonomy teacher-as-teacher autonomy

TA can be defined as teacher's ability and willingness to help learners take responsibility for their own learning. An autonomous teacher is a teacher who reflects on her teacher role and who can change it, who can help learners become autonomous, and who is independent enough to let her learners become independent.

TA includes two parts according to the phases of development. In preservice teacher education, the (student) teacher learns how to teach as a learner of teaching, and inservice teacher teaches students how to learn as a teacher of learning.

The professional attribute, on one hand, involves the capacity of control over the teaching process. On the other hand, the professional attribute relates to the capacity for self-directed professional development.

$\mathrm{Xu}$ (2007, p. 202)

Action for autonomous teaching and Capacity for self-directed professional TA includes: teacher's freedom from control in the teaching process, and as language learners, teacher should have the capacity of autonomous learning. development

\subsection{A Working Definition for Language Teacher Autonomy}

As is listed above, the heated debate about the definition of teacher autonomy has taken in many literature works. 
For example, whether teacher autonomy should be thought of as a kind of capacity or behavior; whether it is characterized by teacher responsibility or teacher control; whether it is a psychological phenomenon with political implications or a political right with psychological implications.

From the two mainstream of views on teacher autonomy, it is quite complex to conclude a simple definition. In the present paper, we adopt and create a working definition of teacher autonomy based on what is proposed by Huang and Benson (2007). Language teacher autonomy refers to the professional attribute of language teacher, which involves teacher's professional freedom (from control by others), teacher's ability/capacity and willingness to take action for self-directed professional development.

Teacher autonomy has the following three important characteristics. Firstly, teacher autonomy refers to language teacher's freedom and willingness of autonomous teaching. Language teacher is willing to take an active, critical and reflective attitude towards his or her language teaching, and also takes the initiative to be responsible for the teaching and learning process by accommodating the factors that impede language teaching and learning. Although language teacher tend to be affected by language policy, the rules and regulations of institutions, and old teaching tradition, language teacher need to effect his or her efficacy to create space and freedom that is conducive for learners to take charge of their study.

Secondly, teacher autonomy is viewed as teacher capacity. This means that language teachers not only impart knowledge and develop learners' language skills, but more importantly, language teachers need to know the theory, methods and approaches, and significance about how to cultivate learner autonomy. Through learner training and teacher support, language learner can develop the capacity to learn independently.

Last but not least, teacher autonomy involves teacher action in accommodating and making full use of the teaching environment or context. The development of language teacher autonomy was affected by the political, social, cultural and educational context. Therefore, the administration of the institutions and teacher educators should respect and learn of teacher development needs, facilitate the conditions, environment, and context that are conducive to the development of teacher autonomy.

Based on the above discussion, teacher autonomy is viewed as the constructive process how language teachers willingly develop their autonomy within the supportive environment or context.

\section{Summary}

As regards to the future development of teacher autonomy, one important issue which needs to be paid attention to is initial teacher training. Many of the teachers note that how they were taught, whether in a traditional or innovative way, was an important factor in determining their own pedagogical approach. As learner autonomy is intricately intertwined with the language teacher's professional understanding of his/her task, emphasizing the need for the teacher to understand well what learner autonomy is all about as an educational goal. Thus at the pre-service teacher training stage, the teacher educators should be aware of the importance of promoting the autonomy awareness of the student teachers. Then a series of courses and practicum should be designed to well facilitate the development of the student teacher autonomy.

Secondly, language teaching never takes place in a social vacuum. Therefore, the question of teacher autonomy needs to be examined in the context of a tension between the pedagogic freedom in the classroom and the various constraints in the institutional and society settings. As pointed by Jiménez Raya and Lamb (2008), working towards autonomy in a school context is a question of making a purposeful use of the rich possibilities for personal options and ways of educative action in a situation of coexisting freedom and constraint.

Thirdly, in addition to considering the contextual factors providing both incentives, possibilities and constraints to introducing autonomy in the classroom, Kohonen (2008) points out that the teacher needs to develop a critical understanding of the nature of autonomy.

To sum up the discussion on teacher autonomy, we will quote what Sampedro (2008, p. 129) wrote about autonomy:

"Autonomy is primarily a state of mind, an attitude to life. It has to do with the belief in one's potential, self-esteem, open-mindedness, self-respect and respect for others, etc. At the same time it has to do with the development of the ability to act autonomously and the ability to learn in general, or to learn a given subject in particular".

As far as the development of language teacher's autonomy is concerned, it is a complex and complicated process, but yet a worthwhile educational goal to achieve. 


\section{Acknowledgements}

This research was supported by "the Fundamental Research Funds for the Central Universities" (Grant NO. 13QN54).

\section{References}

Anderson, L. W. (1987). The decline of teacher autonomy: Tears or cheers? International Review of Education, 33, 357-373. https://doi.org/10.1007/BF00615308

Aoki, N. (2000). Affect and the role of teacher in the development of learner autonomy. In J. Arnold (Ed.), Affect in language learning (pp. 142-154). Beijing: Foreign Language Teaching and Research Press.

Aoki, N. (2002). Aspects of teacher autonomy: Capacity, freedom, and responsibility. In P. Benson \& S. Toogood (Eds.), Learner autonomy 7: Challenges to research and practice (pp. 111-124). Dublin: Authentik.

Arnold, J. (Ed.). (2000). Affect in language learning. Beijing: Foreign Language Teaching and Research Press.

Benson, P. (2004). Learner autonomy in the classroom. In D. Nunan (Ed.), Practical English language teaching (pp. 290-308). Beijing: Higher Education Press.

Benson, P. (2005). Teaching and researching autonomy in language learning. Beijing: Foreign Language Teaching and Research Press.

Benson, P. (2006). Autonomy in language teaching and learning. Language Teaching, 40, 21-40. https://doi.org/10.1017/S0261444806003958

Benson, P. (2011). Teaching and researching autonomy (2nd ed.). Harlow: Pearson Education Limited.

Breen, M. P., \& Mann, S. J. (1997).Shooting arrows at the sun: Perspectives on a pedagogy for autonomy. In P. Benson, \& P. Voller (Eds.), Autonomy and independence in language learning (pp.132-149). London: Longman.

Cotterall, S. (1995). Readiness for autonomy: Investigating learner beliefs. System, 23(2), 195-205. https://doi.org/10.1016/0346-251X(95)00008-8

Dickinson, L. (1992). Learner autonomy 2: Learning training for language learning. Dublin: Authentik.

Han, L. G. (2013). Research on university EFL teachers' pedagogical knowledge for the development of learner autonomy. Beijing: Modern Education Press.

Holec, H. (1981). Autonomy and foreign language learning. Oxford: Pergamon Press.

Huang, J., \& Benson, P. (2007). Research on teacher autonomy in second language education. Foreign Languages and Their Teaching, (2), 33-37.

Jiménez Raya, M. (2009). Teacher education for learner autonomy: An analysis of the EuroPAL contribution to a knowledge base. Innovation in Language learning and Teaching, 3(3), 221-238. https://doi.org/10.1080/17501220903404459

Jiménez Raya, M., \& Lamb, T. (Eds.). (2008). Pedagogy for autonomy in modern languages education: Theory, practice, and teacher education. Dublin: Authentik.

Knowles, M. (1975). Self-directed learning: A guide for learners and teachers. Chicago: Association Press.

Kohonen, V. (2008). Commentary on Section I. In M. Jiménez Raya, \& T. Lamb (Eds), Pedagogy for autonomy in modern languages education: Theory, practice, and teacher education (pp. 92-100). Dublin: Authentik.

Little, D. (1991). Learner autonomy 1: Definitions, issues and problems. Dublin: Authentik.

Little, D. (1995). Learning as dialogue: The dependence of learner autonomy on teacher autonomy. System, 23(2), 175-181. https://doi.org/10.1016/0346-251X(95)00006-6

McGrath, I. (2000). Teacher autonomy. In B. Sinclair, I. McGrath, \& T. Lamb (Eds.), Learner autonomy, teacher autonomy: Future directions (pp. 100-110). Harlow: Longman.

Pang, W. G. (2003). Self-regulated learning: Principles and educational applications. Shanghai: East China Normal University Press.

Sampedro, S. (2008). Fostering learner autonomy in a secondary school context. In M. Jiménez Raya, \& T. Lamb (Eds), Pedagogy for autonomy in modern languages education: Theory, practice, and teacher education (pp. 126-142). Dublin: Authentik.

Smith, R. C. (2003). Teacher education for teacher-learner autonomy. In J. Gollin, G. Ferguson, \& H. 
Trappes-Lomax (Eds.), Symposium for language teacher educators: Papers from three IALS Symposia. Edinburgh: University of Edinburgh. https://doi.org/10.1016/S0742-051X(03)00016-7

Thavenius, C. (1999). Teacher autonomy for learner autonomy. In S. Cotterall, \& D. Crabbe (Eds.), Learner autonomy in language learning: Defining the field and effecting change (pp. 159-163). Frankfurt am Main: Peter Lang.

Vieira, F. (2008). Introduction to section III: Teacher education for teacher and learner autonomy. In M. Jiménez Raya, \& T. Lamb (Eds.), Pedagogy for autonomy in modern languages education: Theory, practice, and teacher education (pp. 199-201). Dublin: Authentik.

Voller, P. (1997). Does the teacher have a role in autonomous language learning? In P. Benson, \& P. Voller (Eds.), Autonomy and independence in language learning (pp. 98-113). London: Longman.

Xu, J. F. (2007). Autonomy in College foreign language learning: From theory to practice. Beijing: China Social Sciences Press.

\section{Copyrights}

Copyright for this article is retained by the author(s), with first publication rights granted to the journal.

This is an open-access article distributed under the terms and conditions of the Creative Commons Attribution license (http://creativecommons.org/licenses/by/4.0/). 